Фролов В. С., к.військ.н., с.н.с., (ORCID 0000-0003-0105-6439);

Саганюк Ф. В., к.ю.н., доцент, (ORCID 0000-0002-9516-0562);

Павленко В. I., к.військ.н., (ORCID 0000-0002-4313-3079);

Мудрак Ю. М., (ORCID 0000-0002-1159-5746)

Центр воєнно-стратегічних досліджень Національного університету оборони України імені Івана Черняховського

\title{
Правові та організаційні засади оборонного огляду сил оборони, підвищення їх бойової потужності через посилення спроможності
}

Резюме. Розглянуто правові та організаційні засади оборонного огляду сил оборони, підвищення їх бойової потужності через посилення спроможності, наближення до стандартів, прийнятих в арміях держав-членів НАТО. потужності.

Ключові слова: засади; оборонний огляд; сили оборони; оборонні спроможності; бойові

Постановка проблеми. У сучасних безпекових умовах, коли Росія продовжує агресивні дії проти України з використанням різноманітних гібридних технологій, підвищення бойової потужності Збройних Сил та інших складових сил оборони і посилення ï спроможності для ефективного застосування й активної протидії агресору набуває все більшої актуальності.

Ключовими завданнями для розв'язання зазначеної проблеми мають стати результати оборонного огляду сил оборони та Стратегія воєнної безпеки України, яка має розроблятися Міністерством оборони України за результатами оборонного огляду після затвердження Стратегії національної безпеки України, що визначено Законом України "Про національну безпеку України” від 21 червня 2018 року № 2469-VIII [1].

Зазначена робота ще недостатньо активізована i потребує більш грунтовного дослідження та наукового обгрунтування, оскільки належний порядок проведення оборонного огляду сил оборони для підвищення їх бойової потужності через посилення спроможності поки нормативно не визначений.

Аналіз останніх досліджень i публікацій. Певні правові, організаційні та методологічні засади i рекомендації щодо проведення оборонного огляду в Міністерстві оборони та Збройних Силах України, крім передбачених зазначеним вище законом, були затверджені наказом МО України від 13.05.2018 № 303, який відповідно до наказу МO України від 31.03.2016 року № 174 втратив чинність. Щоправда, частина 3 них i нині використані для здійснення оборонного планування в Міністерстві оборони і Збройних Силах України на основі спроможностей [2], у Тимчасових рекомендаціях із проведення огляду спроможностей за функціональними групами спроможностей в Міністерстві оборони України, Збройних Силах України та інших складових сил оборони, затверджених Міністром оборони України 18 жовтня 2018 року, а також у Порядку проведення оборонного огляду Міністерством оборони України, затвердженому Кабінетом Міністрів України 31 жовтня2018 року.

Аналіз цих нормативно-правових актів показує, що викладені у них положення конкретних шляхів, механізмів і методик та необхідних форм документів із проведення оборонного огляду, особливо в інших складових сил оборони Міністерством оборони, як визначено у заголовку затвердженого КМ України Порядку, не містять. Ці правові та методологічні засади потребують певної конкретизації й унормування, наприклад, у Методичних рекомендаціях Міністерства оборони, як це було передбачено зазначеними раніше документами.

Науково-методичні та деякі практичні засади й досвід проведення оборонного огляду в Міністерстві оборони та Збройних Силах України наведені у наукових працях військових фахівців, зокрема І. С. Руснака, М. М. Дєнєжкіна, П. М. Крикуна, В. М. Можаровського та інших [3, 4]. Проте вони, як і згадані вище нормативно-правові акти потребують певного вдосконалення та наближення до теперішніх потреб і стандартів армій держав-членів НАТО, 
що вимагає відповідного фахового обговорення й дослідження.

Метою статті $є$ дослідження правових та організаційних засад проведення оборонного огляду в силах оборони й обгрунтування відповідних рекомендацій щодо їх вдосконалення в сучасних умовах для розроблення належної Стратегії воєнної безпеки України та інших нормативноправових актів, підвищення ефективності їх бойової потужності через посилення спроможностей.
Викладення основного матеріалу. Оборонний огляд, за визначенням Закону України "Про національну безпеку України" від 21.06.2018 № 2469-VIII - це "процедура оцінювання стану і готовності сил оборони до виконання завдань $з$ оборони України, стану їх кадрового, фінансового, матеріального та інших видів забезпечення" [1, п. 11 ст. 1]. Саме ці й інші визначені законом засади та індикатори становлять правову і організаційну основу (засади) оборонного огляду сил оборони (табл. 1).

Таблиця 1

Правові та організаційні засади оборонного огляду сил оборони

\begin{tabular}{|c|c|c|c|}
\hline $\begin{array}{l}\text { № } \\
\text { 3/II }\end{array}$ & Індикатори & Сутність & $\begin{array}{c}\text { Визначено } \\
\text { Законом [1] }\end{array}$ \\
\hline 1 & $\begin{array}{c}\text { Поняття } \\
\text { оборонного } \\
\text { огляду (ОО) }\end{array}$ & $\begin{array}{l}\text { Це процедура оцінювання: } \\
\text { стану і готовності сил оборони (СО) до виконання завдань щодо оборони України; } \\
\text { стану кадрового, фінансового, матеріального та інших видів забезпечення СО }\end{array}$ & пп. 11 ст. 1 \\
\hline 2 & Ознаки & $\begin{array}{l}\text { Проиедура оцінювання стану і готовності СО: } \\
\text { складова комплексного огляду сектору безпеки і оборони; } \\
\text { суб’єкти оборонного огляду - сили оборони. }\end{array}$ & $\begin{array}{l}\text { пП. } 11 \text { ст. } 1 \\
\text { п. } 1 \text { ст. } 27 \\
\text { Пп. } 11 \text { ст. } 1\end{array}$ \\
\hline 3 & $\begin{array}{c}\text { Мета } \\
\text { Проведення }\end{array}$ & $\begin{array}{l}\text { 3бір об'єктивних даних для: } \\
\text { розроблення та уточнення концептуальних документів розвитку складових сектору } \\
\text { безпеки і оборони (СБіО); } \\
\text { визначення заходів, спрямованих на досягнення ними необхідних спроможностей до } \\
\text { виконання завдань за призначенням у поточних і прогнозованих умовах безпекового } \\
\text { середовища }\end{array}$ & п. 8 ст. 1 \\
\hline 4 & $\begin{array}{l}\text { Порядок } \\
\text { проведення та } \\
\text { звітування }\end{array}$ & $\begin{array}{l}\text { 1. Здійснюється: } \\
\text { у рамках комплексного огляду відповідно до Стратегії НБУ та ін. документів } \\
\text { довгострокового планування; } \\
\text { за рішенням РНБО у разі необхідності може проводитися окремо. } \\
\text { Міністерством оборони України (МО) до повноважень якого належать: } \\
\text { організація в СО заходів оборонного планування; } \\
\text { визначення засад воєнної, військової кадрової та військово- технічної політики у } \\
\text { сфері оборони; } \\
\text { координації діяльності державних органів та місцевого самоврядування щодо } \\
\text { підготовки держави до оборони; } \\
\text { звітність про результати огляду МО надає на розгляд та затвердження РНБО } \\
\text { України. } \\
\text { 2. Порядок проведення визначає КМ України }\end{array}$ & $\begin{array}{l}\text { п. } 1 \text { ст. } 27 \\
\text { п. } 1-2 \text { ст. } 15\end{array}$ \\
\hline 5 & $\begin{array}{l}\text { Шляхи реалізації } \\
\text { результатів ОО }\end{array}$ & $\begin{array}{l}\text { 1. Формування перспективної моделі СБіО; } \\
\text { 2. Нарощування спроможностей складових СБіО для виконання завдань за } \\
\text { призначенням; } \\
\text { 3. Формування боєздатних, мобільних, підготовлених на належному рівні, всебічно } \\
\text { забезпечених сил безпеки (СБ) і СО, здатних захистити національні інтереси } \\
\text { України та брати активну участь у міжнародних заходах із підтримання миру і } \\
\text { безпеки; } \\
\text { 4. Розроблення МО за рішенням РНБО (після затв. Стратегії НБУ) Стратегії воєнної } \\
\text { безпеки України як основи для розроблення СОБ України, програмних документів } \\
\text { з питань оборони і розвитку СО, ОВТ, оперативних планів і планів застосування } \\
\text { сил та засобів оборони. }\end{array}$ & п. 1 та 3 ст. 28 \\
\hline
\end{tabular}

Відповідно до зазначеного закону [1, п.3, ст. 27] порядок оборонного огляду, а також інших передбачених цим законом оглядів, що включені до комплексного огляду, визначається Кабінетом Міністрів України. Такий документ, а саме Порядок проведення оборонного огляду Міністерством оборони Урядом нещодавно затверджений. Однак у зв'язку 3 потребою ефективнішого його впровадження в силах оборони, наближення до потреб сьогодення та відповідних стандартів, прийнятих в арміях держав-членів НАТО, Міністерству оборони разом 3 іншими складовими сил оборони доцільно розробити необхідні Методичні рекомендації щодо організації та проведення оборонного огляду сил оборони й затвердити їх наказом Міністерства оборони за погодженням 3 керівниками інших складових сил оборони. Цим документом на основі досвіду державчленів НАТО бажано рекомендувати проводити оборонний огляд у складових сил оборони не тільки задля розвитку необхідних їм спроможностей для виконання завдань за призначенням, а для обгрунтування шляхів i механізмів підвищення ефективності їх бойових потужностей через додаткові та посилені спроможності для застосування, у разі 
необхідності, та оборони держави “ $у$ поточних $i$ прогнозованих умовах безпекового середовища", як визначено п. 8 ст. 1 зазначеного закону.

Бойові потужності в арміях державчленів НАТО визначаються як сума руйнівних, конструктивних та інформаційних спроможностей, яких війська можуть набувати. До них відносять вісім елементів таких потужностей, а саме, керівництво, інформацію, переміщення i маневр, розвідувальне забезпечення бойових дій, вогневе ураження, життєзабезпечення, командування та управління і захист. Про це йдеться у їхніх бойових документах $\mathrm{i}$ Військовому посібнику (FM 3.0), який рекомендується Генеральним штабом Збройних Сил України для використання в Україні [5].

Військовий посібник містить $\mathrm{i}$ деякі застереження, згідно з якими бойові потужності мають виражатися не тільки у кількісній формі, а й у порівнянні 3 "потужноостями та спроможсностями противника", бо у воєнних операціях потужність військ (сил) $є$ визначальною засадою i орієнтиром для нарощування іiі через посилення необхідних спроможностей.

Базові категорії спроможностей (Capability categories) в арміях більшості держав-членів НАТО уніфіковані. Їх абревіатура складається із початкових букв $D O T M L P F I$ (табл. 2).

Таблиця 2

Уніфіковані базові компоненти спроможностей, що застосовуються в арміях держав-членів НАТО [6, с.130-132]

\begin{tabular}{|c|c|c|c|c|c|}
\hline Складові спроможностей & США & Канада & $\begin{array}{c}\text { Велика } \\
\text { Британія }\end{array}$ & Австралія & Болгарія \\
\hline $\begin{array}{l}\text { Doctrine } \\
\text { Доктрина, концуепциія }\end{array}$ & $\bullet$ & $\bullet$ & $\bullet$ & & • \\
\hline $\begin{array}{l}\text { Organization } \\
\text { Організація }\end{array}$ & $\bullet$ & • & • & • & \\
\hline $\begin{array}{l}\text { Training } \\
\text { Колективна підготовка }\end{array}$ & $\bullet$ & $\bullet$ & $\bullet$ & $\bullet$ & $\bullet$ \\
\hline $\begin{array}{l}\text { Materiel } \\
\text { Логістика } \\
\text { Озброєння }\end{array}$ & $\bullet$ & $\bullet$ & $\bullet$ & $\bullet$ & $\bullet$ \\
\hline $\begin{array}{l}\text { Leadership } \\
\text { Командування і управління }\end{array}$ & $\bullet$ & $\bullet$ & & $\bullet$ & $\bullet$ \\
\hline $\begin{array}{l}\text { Personne } \\
\text { Персонал }\end{array}$ & $\bullet$ & $\bullet$ & $\bullet$ & $\bullet$ & $\bullet$ \\
\hline $\begin{array}{l}\text { Facilities } \\
\text { Інфраструктура }\end{array}$ & $\bullet$ & $\bullet$ & $\bullet$ & $\bullet$ & $\bullet$ \\
\hline $\begin{array}{l}\text { Interoperability } \\
\text { Взаємосумісність }\end{array}$ & $\bullet$ & & & & $\bullet$ \\
\hline
\end{tabular}

Вирішальним серед зазначених компонентів у Військовому посібнику визнається керівництво та майстерність командирів [5, p. 4]. Саме вони уповноважені осмислювати спроможності 3 огляду на потреби підвищення бойових потужностей для ведення ефективних бойових дій через посилення або розвиток відповідних компонентів спроможностей, які стосуються, передусім, стану фахової майстерності керівництва складовими сил оборони й військового управління.

Разом із наведеним під час оборонного огляду військ (сил) потрібно враховувати і те, що система військового управління за стандартами НАТО істотно відрізняється від нинішньої у Збройних Силах України, у першу чергу, організаційно-штатною структурою штабів усіх рівнів. Зокрема, в основу їхнього об' єднаного штабу “Joint staff" покладено розподіл за функціональним принципом. Завдання щодо планування та управління поточними операціями покладаються на структурний підрозділ J-3, до складу якого входять секції планування, оперативного забезпечення, вогневого ураження, обробки та аналізу ведення поточної операції. Функції перспективного планування операцій i військово-цивільного співробітництва (планування гуманітарних дій, контакти 3 місцевим населенням i органами влади, допомога у ліквідації наслідків ведення бойових дій тощо) покладені на підрозділ J-5. Матеріально-технічним забезпеченням військ (сил) опікується підрозділ J-4.

Особливим $\epsilon$ підрозділ $\mathrm{J}-7$, на який покладаються завдання 3 розроблення, коригування, уточнення i затвердження керівних документів, що встановлюють порядок підготовки військ (сил) відповідно до ix оперативного (бойового) призначення та визначених форм застосування, що встановлено відповідними керівними документами [6, с.109114]. 
В Україні відповідальність за підготовку програм, що розробляються для посилення обороноздатності держави покладені на Міністра оборони [1, ст. 33]. Інші міністерства та центральні органи виконавчої влади вносять пропозиції на розгляд Кабінету Міністрів України та Ради національної безпеки і оборони України щодо стратегічних документів та 3 коригування державних цільових оборонних програм; розробляють плани утримання i розвитку відповідних органів сектору безпеки і оборони, бюджетні запити та сукупність документів державного оборонного замовлення на плановий бюджетний період, а також пропозиції до прогнозних показників видатків Державного бюджету України. Проте, фінансове забезпечення сектору безпеки і оборони між силами оборони не розмежовано.

$\mathrm{He}$ менш прискіпливу оцінку під час оборонного огляду сил оборони доцільно приділити організаційній складовій їх спроможностей, у першу чергу в порівнянні 3 потужсностями та спроможностями противника, який на Сході України проявив себе як агресор. Тут, як наведено у публікаціях, агресор сконцентрував поблизу кордону України потужні військові угруповання навіть 3 боку Білорусі [7]. Вони готові до ведення широкомасштабної війни. Особливо тут налагоджене агресором і військове управління (рис. 1).

\section{Система управління 1 та 2 армійськими корпусами російсько-окупаційних військ на тимчасово окупованих територіях України}

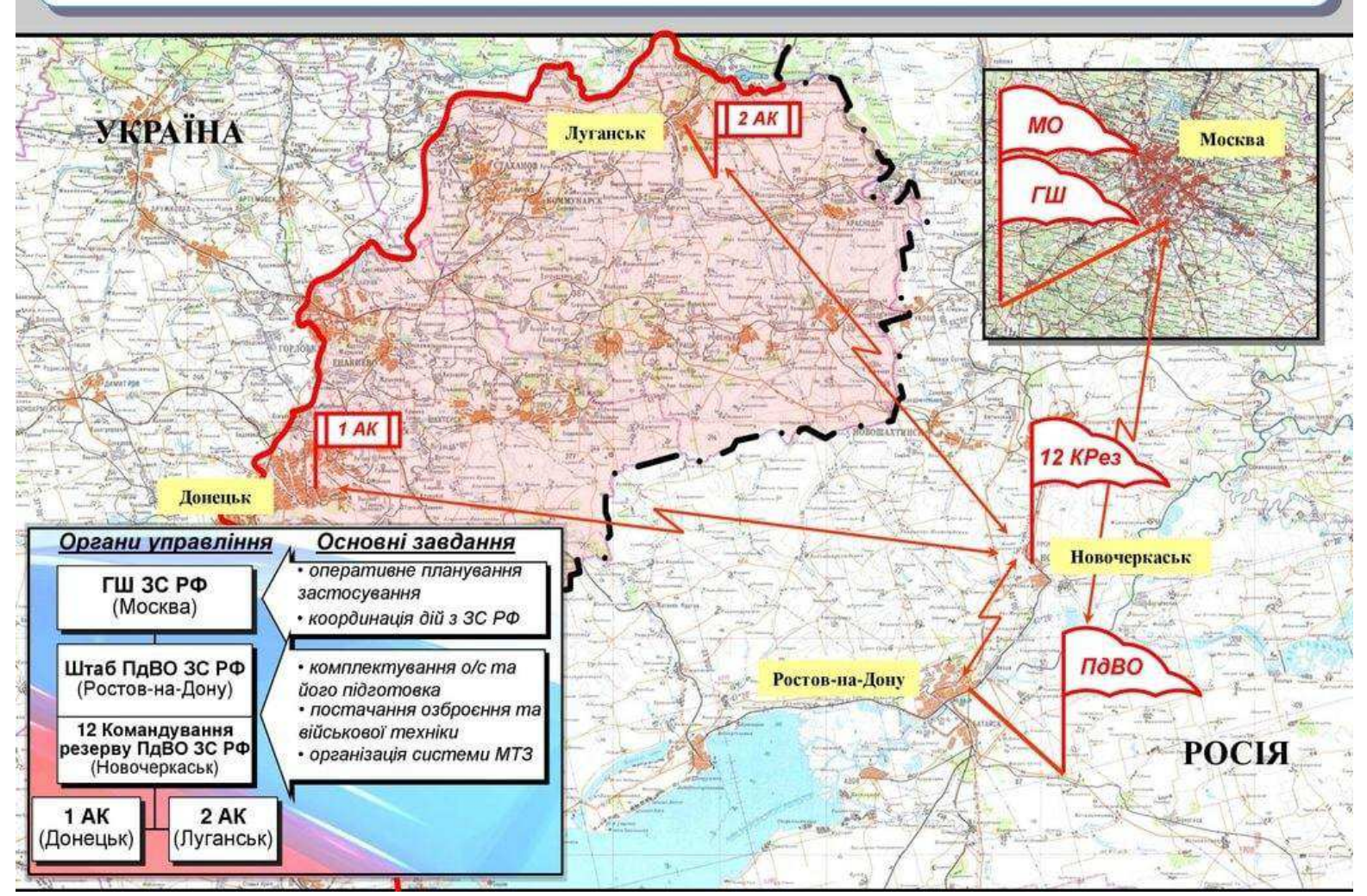

Рис. 1. Система військового управління окупаційними угрупованнями на Донбасі [8]

$\mathrm{He}$ менш небезпечними належить сприймати й інші потужності та спроможності окупаційних військ агресора, які мають бути предметом прискіпливої оцінки та врахування під час оборонного огляду сил оборони, а за його результатами, i у процесі прийнятті адекватних рішень та документів нормативноправового характеру щодо підвищення їх бойової потужності шляхом посилення певних компонентів спроможностей для ефективної протидії агресору, захисту і оборони держави. Це має бути ключовим індикатором оборонного огляду сил оборони.

\section{Висновки}

1. Правові та організаційні засади оборонного огляду сил оборони визначені Законом України "Про національну безпеку України" та іншими виданими на його виконання нормативно-правовими актами. Для їх ефективної реалізації в силах оборони вони потребують певної конкретизації, методологічного наповнення та методичного забезпечення, визначення єдиних форм документів, що мають розроблятися та надаватися складовими сил оборони Міністерству оборони для узагальнення й 
прийняття подальших рішень. Такі Методичні рекомендації щодо організації та проведення оборонного огляду сил оборони доречно розробити і затвердити наказом Міністерства оборони за погодженням з керівниками інших складових сил оборони.

2. Для наближення процедур оборонного огляду сил оборони в Україні до принципів і стандартів, прийнятих в арміях держав-членів НАТО, доцільно покласти у їх основу вимогу щодо оцінки, у першу чергу, потужності та спроможності військ (сил) і засобів противника для підвищення до необхідного рівня бойової потужності Збройних Сил України та інших складових сил оборони через посилення певних спроможностей для надійного протистояння їх агресору і захисту України та активної іiі оборони, як цього вимагає чинна Воєнна доктрина (п. 21, 22).

Напрям подальших досліджень. Для якісної підготовки і проведення в Україні оборонного огляду сил оборони доцільно вдосконалити певні методологічні та організаційні засади, а також методику i способи ефективної їх реалізації на практиці, наблизити до принципів i стандартів, прийнятих в арміях держав-членів НАТО для підвищення бойових потужностей сил оборони через посилення необхідних їм спроможностей.

\section{СПИСОК ВИКОРИСТАНОЇ ЛІТЕРАТУРИ}

1. Закон України "Про національну безпеку України” від 21 червня 2018 року № 2469-VIII. URL: http://zakon0.rada.gov.ua/laws/show/246919/page2.

2. Рекомендації з оборонного планування на основі спроможностей в Міністерстві оборони України та Збройних Силах України: затв. МО України 12 червня 2017 року.

3. Дєнєжкін М. М., Крикун П. М., Р Руснак I. С. Проблеми проведення комплексного огляду сектору безпеки і оборони України: погляди на його організацію та вирішення завдань // Наука i оборона.2014. № 4. С. 3-10.

4. Можаровський В. М. Оборонний огляд в Україні: результати і висновки // Наука і оборона. 2012. № 4. C. 3-11.

5. Військовий посібник 3.0. Операції. К.: ГШ ЗС України, 2016. 123 с.

6. Сектор безпеки і оборони України: стратегічне керівництво та військове управління. К.: МО та ГШ 3С України, 2018. 230c. URL: http:// nuou.org.ua/ pro-university/ dokumenty/finish/30monohrafii/1938-sektor-bezpeky-i-oborony-ukrainystratehichne-kerivnytstvo-ta-viiskove-upravlinnia/ 0.html

7. Російська армія оточує Україну. URL: https://antikor.com.ua/articles/91076-

rosijsjka_armija_otochuje_ukrajinu

8. Сьогодні. 2018. 13 квітня. URL: https://ukr.segodnya.ua/politics/turchinov-ugranicukrainy-stoit-ogromnoe-voysko-rf-gotovoe-kbolshoy-voyne-1130418.html

Стаття надійшла до редакційної колегії 24.10.2018

Фролов В. С., к.воен.н., с.н.с.; Саганюк Ф. В., к.ю.н., доцент;

Павленко В. И., к.воен.н.; Мудрак Ю. М.

Центр военно-стратегических исследований Национального университета обороны Украины имени Ивана Черняховского, Киев

\section{Правовые и организационные основы оборонного смотра сил обороны, повышения их боевой мощи путем усиления возможности}

Резюме. Рассмотрены правовые и организационные основы оборонного смотра сил обороны, повышения их боевой мощи путём усиления возможностей, приближения к стандартам, принятым в армиях государств-членов НАТО.

Ключевые слова: основы; оборонный смотр; силы обороны; оборонные возможности; боевая мощь.

V. Frolov, PhD (Military), senior researcher;

F. Saganiuk, PhD, assistant professor;

V. Pavlenko, PhD (Military);

Y. Mudrak

Center for Military and Strategic Studies of the National Defence University of Ukraine named after Ivan Cherniakhovskyi, Kyiv

Legal and organizational foundations of the Defense Forces Defense Review, increasing their combat power through capacity building

Resume. The legal and organizational bases of the Defense Forces Defense Review, increase of their combat power through capacity building, approximation to standards adopted in the armed forces of NATO member states are considered.

Keywords: foundations; defense review; defense forces; defensive capabilities; combat power. 